\title{
Comparative Study of Different Type of Flat Slab and Conventional Slab for an RC Structure Under Earthquake Loading
}

\author{
Renuka Gurusiddappa Madiwalar and Vinayak Vijapur
}

\begin{abstract}
Now days, in construction activity flat slab are using quite common, mainly in public structures. Flat slab are normally used for the structure due to various advantages of flat slab system over conventional slab system mainly, due to its reduced height of the storey, minimizes the construction period, most economical and because of its good aesthetic appearance. The flat slab is poor performance under seismic loading, so it is necessary know the seismic behaviour of structure with flat slab and conventional slab.

In the present study, structures having conventional slab and flat slab has been analysed under the earthquake loading using ETABS version 13.1.2. Equivalent static method comparative analysis of conventional slab, flat slab without drop, flat withdrop, flat slab with column head and flat with both drop and column head. And we are considering 5 $(\mathrm{G}+4)$ storey, $10(\mathrm{G}+9)$ storey, $15(\mathrm{G}+14)$ storey. The same buildings were studied for different seismic zone which are located in zone II, zone III, zone IV, and zone V and taking soil type II. Also parameters like Lateral Displacement, Storey Drifts, Storey Shear, Design Base Shear, and Axial Forces are studied.
\end{abstract}

Keywords--- Flat Slab, Storey Dift, Lateral Displcement, Base Shear.

\section{INTRODUCTION}

$I^{\mathrm{s}}$ NDIA is fast developing country as well as India have got second place in population in the world which in turn brings demand of living area along with the growth of population. Now days the demand of area for construction is going on increasing everywhere.

To overcome from this problem only one solution is vertical development. So vertical development will increase the height of storey and it should be resist the additional load like earthquake and wind load.

The major material for the construction of all civil engineering structures is Reinforced Concrete. Earlier reinforced concrete used only for some parts of the structure, now day's reinforced concrete is used for civil infrastructure. Increase of tall structure to study the lateral load like wind and

Renuka Gurusiddappa Madiwalar, M.Tech., Student, Department of Civil Engineering, Government Engineering College, HAVERI, Karnataka, India. E-mail:renuka.g.madivalar@gmail.com

Vinayak Vijapur, Assistant Professor, Department of Civil Engineering, Government Engineering College, HAVERI, Karnataka, India. E-mail: vinayaka.pv@gmail.com,vinayaka_pv@yahoo.co.in DOI:10.9756/BIJMMI.8156 earthquake is very important. So RC structure should resist the earthquake load and wind load. During the earthquake the structure will damage due to some reasons that is code imperfections, error in analysis, and error in design.

The common frame construction is column, beam and slabs. Common construction practice is the slab will support by beam and beam will support by column. This type of construction is called beam and slab construction. However in public halls, public offices and houses, for this type of structure normally they avoid the beam and slab construction. Instead of beam slab they will introduce without beam construction. For such cases RC flat slabs are used. When the slab will directly rest on column without beam and directly load will transfer from slab to column this type of construction will called flat slab or beamless slab. Because of many advantages the flat slab is widely used as it reduces the height of the storey, minimizes the construction period, most economical and because of its good aesthetic appearance.

However, compression made between beam-column construction and flat slab we can see the lower stiffness in the flat slabs which can causes to relatively more deflections. Due to these reasons shear capacity of the flat slab will reduces around the column. So the main failure in the flat slab is Flexural failure and Punching shear failure. The Slabs where mainly failed to flexural failure; the mode of the failure is ductile, due to this relatively more deflection under load. Bottom surface crack will appear before failure occurs, this shows the failure mode. The punching shear failure is mode of brittle failure, the failure occur due to shear reinforcement absent.

\section{PROBLEM DEFINITION}

In the present study, an attempt has been made to evaluate the behavior of different type of flat slab and conventional slab. We are considering a multi-storey building with different types of RC slab system for different height of stories. The structure consists of 6 numbers of bays, in both-direction $(\mathrm{X} \& \mathrm{Y})$; length of each bay is equal to 5.5meter. For modeling and analysis of structure, we are using ETABS software 13.1.2 version. ETABS software is nonlinear software and the structure is modeled for different stories height. In this study we are considering $5(\mathrm{G}+4)$ storey, $10(\mathrm{G}+9)$ storey, 15 $(\mathrm{G}+14)$ storey. Both buildings are modelled in Etabs software and subjected to gravity and dynamic loads are analysed by equivalent static analysis. The same buildings were studied for different seismic zone which are located in zone II, zone III, zone IV, and zone V and taking soil type II. Buildings having 
grade of concrete for beam, column, and slab is M40 with unit weight of concrete being $25 \mathrm{kN} / \mathrm{m}^{3}$. Live load on floor $3 \mathrm{kN} / \mathrm{m}^{2}$, on terrace $1.5 \mathrm{kN} / \mathrm{m}^{2}$ and floor finish $1 \mathrm{kN} / \mathrm{m}^{2}$. Building having column size form ground floor to $5^{\text {th }}$ flooris $1.0 \mathrm{mx} 1.0 \mathrm{~m}, 6^{\text {th }}$ to $10^{\text {th }}$ floor is $0.8 \mathrm{mx} 0.8 \mathrm{~m}$, and 11 th to $15^{\text {th }}$ floor is $0.6 \mathrm{mx} 0.6 \mathrm{~m}$. Thickness of conventional slab is 0.15 meter, flat slab without drop is $0.20 \mathrm{~m}$, thickness of drop is $0.25 \mathrm{~m}$, and thickness of column head is $0.30 \mathrm{~m}$. The building having each storey height 3.6meter.

\section{MODELING AND ANALYSIS}

For the study, here five types of model are considered they are listed as below;

Model 1: Building with conventional slab.

Model 2: Building with flat slab without drop.

Model 3: Building with flat slab with drop.

Model 4: Building with flat slab with column head.

Model5: Building with flat slab both column head and drop.
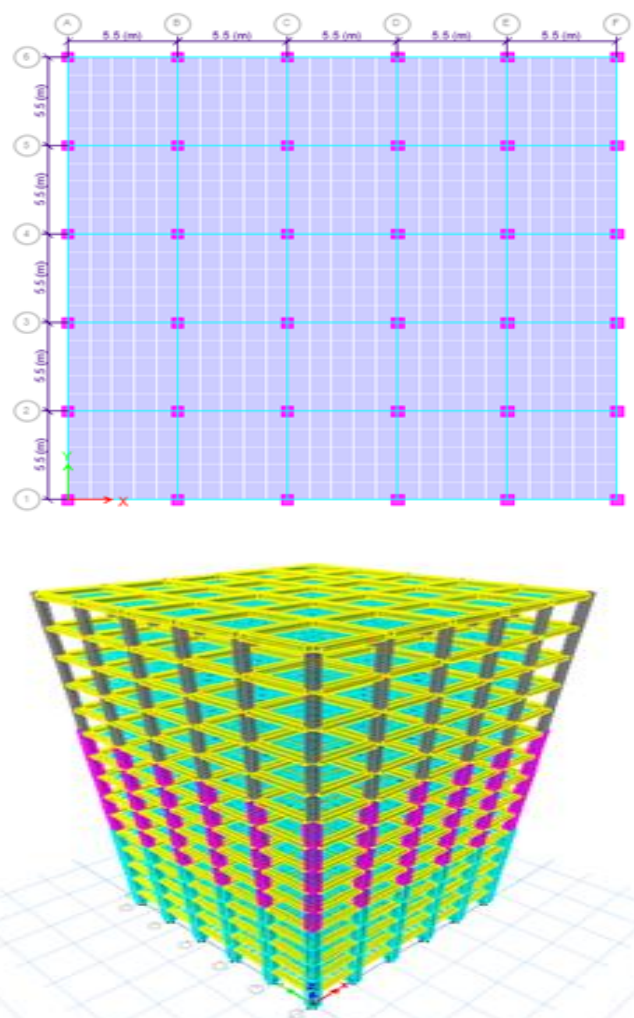

Figure 1: Plan and 3D View of Conventional Slab
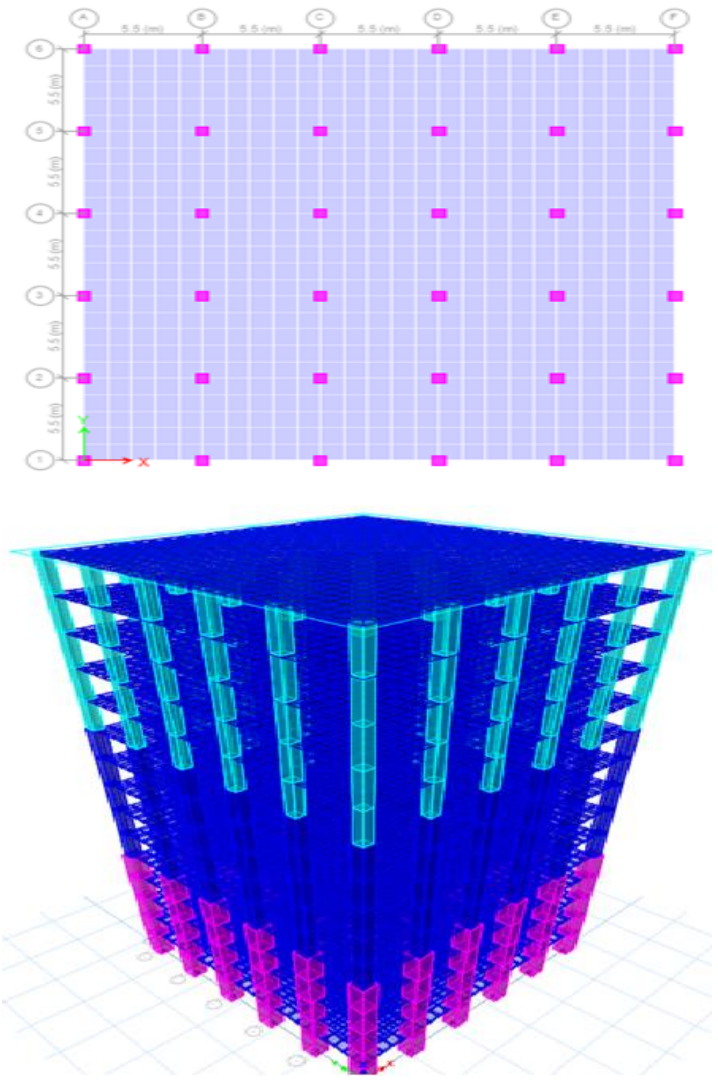

Figure 2: Plan and 3D View of Flat Slab without Drop

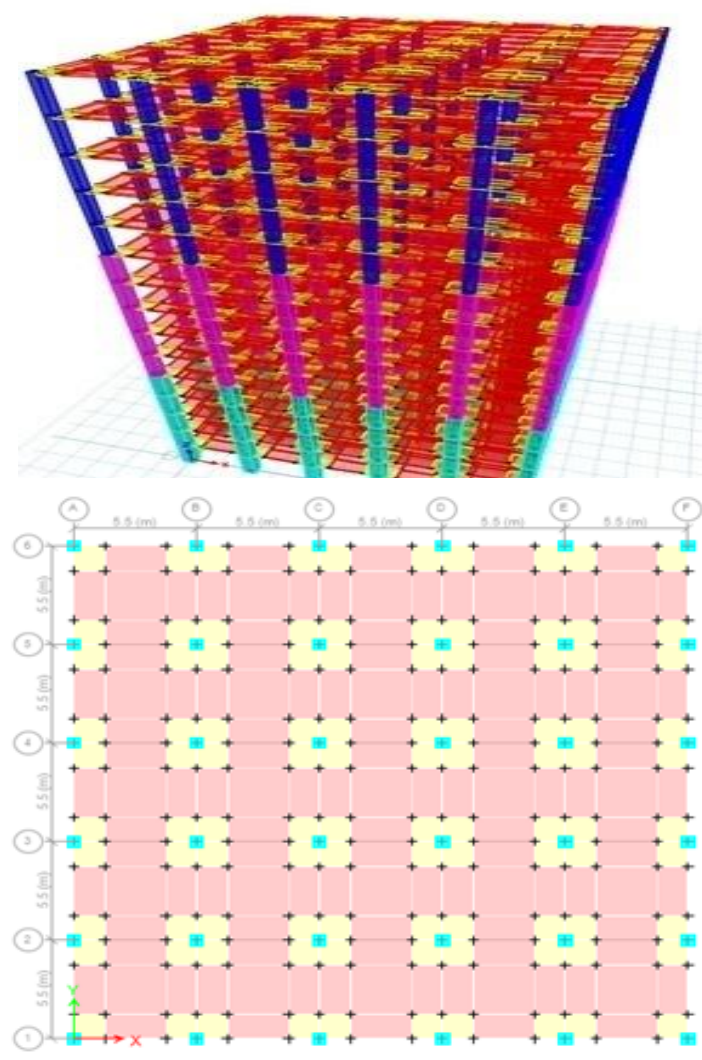

Figure 3: Plan and 3D View of Flat Slab with Drop 

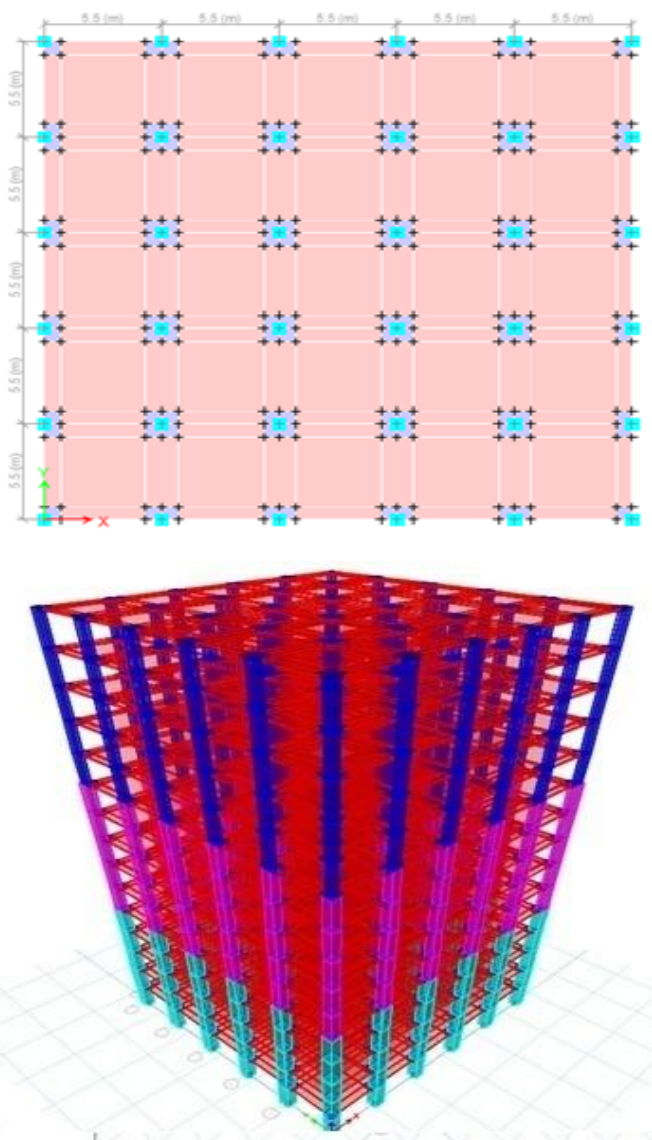

Figure 4: Plan and 3D View of Flat Slab with Column Head
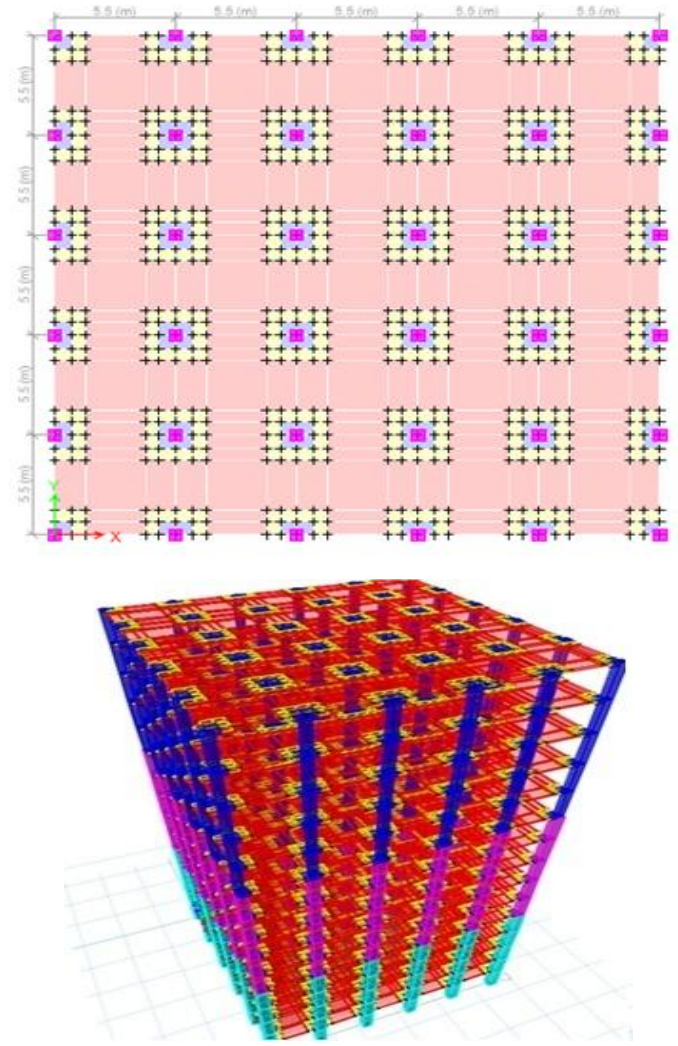

Figure 5: Plan and 3D View of Flat Slab with Both Drop and Column Head

\section{RESUlTS AND DISCUSSIONS}

Seismic analysis is carried out for different types slab conditions. There are five type of model and with different height of building $(18 \mathrm{~m}, 36 \mathrm{~m}$, and $54 \mathrm{~m})$. Liner elastic method of analysis is done. The structures are subjected Seismic load considered for the seismic zones II, III, IV and V with soil type II and results are extracted from ETABS. The results were drawn for parameter like a displacement, storey drift, storey shear and axial forces. The plotted graphs are only for maximum displacement, drift, storey shear, base shear and axial forces and are plotted by linear elastic analysis.

\section{A. Lateral Displacement}

The maximum storey displacement plotted for conventional slab, flat slab without drop, flat slab with drop, flat slab with column head, and flat slab with both drop and column head. The structures were located in seismic zone II, zone III, zone IV, and zone V with soil type II. From the graph we can conclude that the displacement is more in case of flat slab without drop compare to conventional slab system, flat slab with drop and flat slab with column head and flat slab with both drop and column head. And the displacement is nearly equal in between conventional and flat slab with both drop and column head system. The zone $\mathrm{V}$ experienced more lateral displacement.

Table 1: Comparison between Maximum Storey Displacements for 5 Storey Located in Different Zones

\begin{tabular}{|l|l|l|l|l|l|}
\hline \multirow{2}{*}{ ZONE } & \multicolumn{6}{|l}{ Lateral Displacement $(\mathrm{mm})$} \\
\cline { 2 - 6 } & Model 1 & Model 2 & Model 3 & Model 4 & Model 5 \\
\hline Zone II & 5.24 & 12.51 & 10.28 & 9.514 & 8.544 \\
\hline Zone III & 8.865 & 20.03 & 16.454 & 15.105 & 13.67 \\
\hline Zone IV & 12.92 & 29.154 & 24.681 & 22.377 & 20.005 \\
\hline Zone V & 19.4 & 39.022 & 34.611 & 33.871 & 30.758 \\
\hline
\end{tabular}

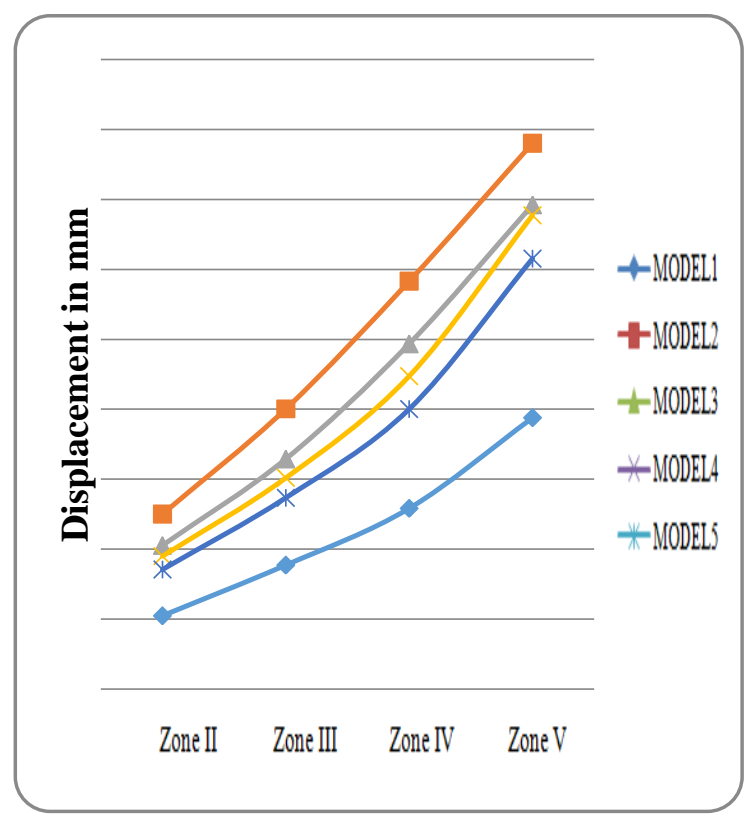

Figure 6: Comparison between Maximum Storey Displacements for 5 Storeys Located in Different Zones 
Table 2: Comparison between Maximum Storey Displacements for 10 Storey Located In Different Zones

\begin{tabular}{|l|l|l|l|l|l|}
\hline \multirow{2}{*}{ ZONE } & \multicolumn{6}{|l}{ Lateral Displacement $(\mathrm{mm})$} \\
\cline { 2 - 5 } & Model 1 & Model 2 & Model 3 & Model 4 & Model 5 \\
\hline Zone II & 15.947 & 26.785 & 19.012 & 19.253 & 16.35 \\
\hline Zone III & 24.236 & 42.758 & 30.419 & 34.227 & 27.109 \\
\hline Zone IV & 36.355 & 64.138 & 45.629 & 46.200 & 37.183 \\
\hline Zone V & 54.531 & 96.207 & 68.443 & 69.319 & 58.66 \\
\hline
\end{tabular}

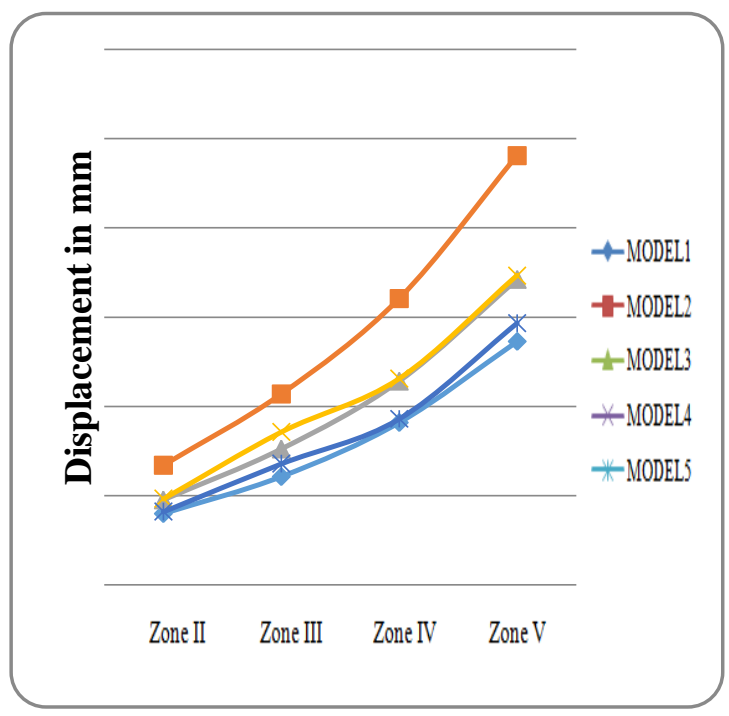

Figure 7: Comparison between Maximum Storey Displacements for 10 Storeys Located in Different Zones

Table 3: Comparison between Maximum Storey Displacements for 15 Storey Located In Different Zones

\begin{tabular}{|l|l|l|l|l|l|}
\hline \multirow{2}{*}{ ZONE } & \multicolumn{6}{|l}{ Lateral Displacement $(\mathrm{mm})$} \\
\cline { 2 - 6 } & Model 1 & Model 2 & Model 3 & Model 4 & Model 5 \\
\hline Zone II & 22.911 & 45.321 & 30.013 & 30.31 & 25.985 \\
\hline Zone III & 36.6 & 55.984 & 48.021 & 48.51 & 41.576 \\
\hline Zone IV & 55.00 & 85.52 & 72.032 & 72.143 & 57.817 \\
\hline Zone V & 82.511 & 125.95 & 108.04 & 109.94 & 86.72 \\
\hline
\end{tabular}

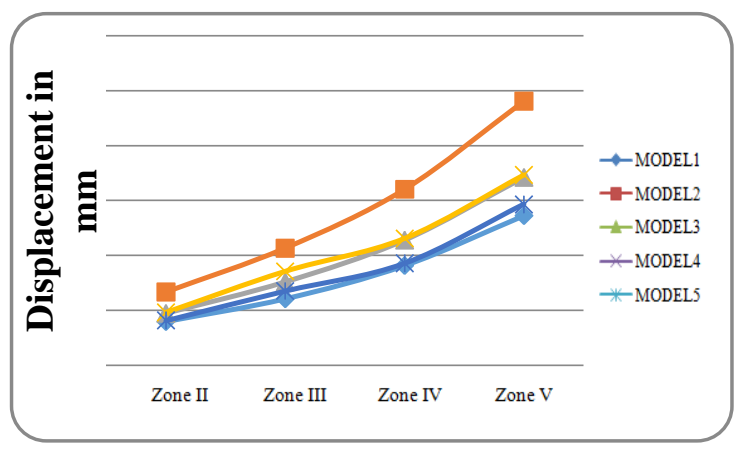

Figure 8: Comparison between Maximum Storey Displacements for 15 Storey Located in Different Zones

\section{B. Storey Drift}

From the graph it is can conclude that the drifts are more in case of flat slab without drop compare to conventional slab system, flat slab with drop and flat slab with column head and flat slab with both drop and column head. And the drifts is nearly equal in between conventional and flat slab with both drop and column head system. The zone $\mathrm{V}$ experienced more storey drifts.
Table 4: Comparison between Maximum Storey Drifts for 5 Storey Located In Different Zones

\begin{tabular}{|l|l|l|l|l|l|}
\hline \multirow{2}{*}{ ZONE } & \multicolumn{5}{|l}{ Storey Drift $(\mathrm{mm})$} \\
\cline { 2 - 6 } & Model 1 & Model 2 & Model 3 & Model 4 & Model 5 \\
\hline Zone II & 0.363 & 0.889 & 0.733 & 0.649 & 0.605 \\
\hline Zone III & 0.613 & 1.423 & 1.173 & 1.067 & 0.968 \\
\hline Zone IV & 0.894 & 2.06 & 1.759 & 1.586 & 1.452 \\
\hline Zone V & 1.089 & 2.73 & 2.52 & 1.789 & 1.678 \\
\hline
\end{tabular}

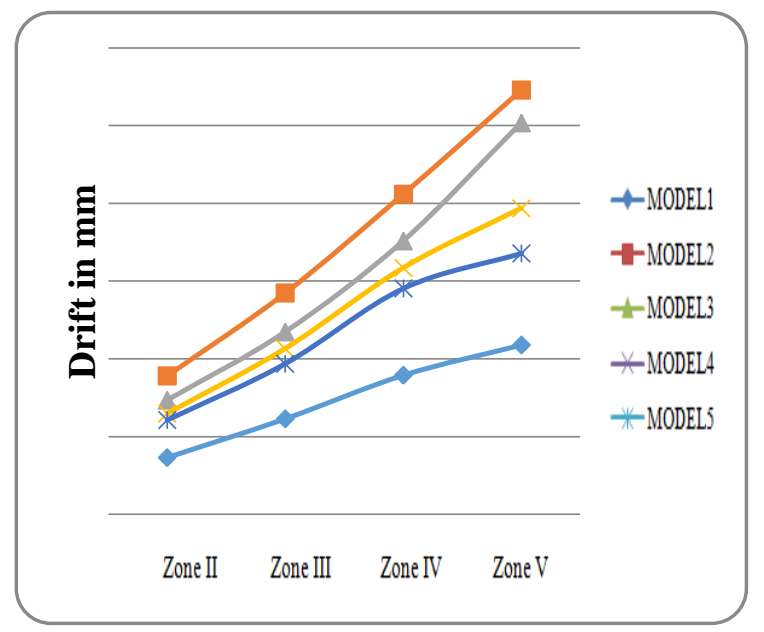

Figure 9: Comparison between Maximum Storey Drifts for 5 Storey Located in Different Zones

Table 5: Comparison between Maximum Storey Drifts for 10 Storey Located In Different Zones

\begin{tabular}{|l|l|l|l|l|l|}
\hline \multirow{2}{*}{ ZONE } & \multicolumn{5}{|l}{ Storey Drift (mm) } \\
\cline { 2 - 6 } & Model 1 & Model 2 & Model 3 & Model 4 & Model 5 \\
\hline Zone II & 0.588 & 1.068 & 0.721 & 0.73 & 0.621 \\
\hline Zone III & 0.941 & 1.847 & 1.153 & 1.299 & 1.028 \\
\hline Zone IV & 1.411 & 2.771 & 1.73 & 1.752 & 1.416 \\
\hline Zone V & 2.117 & 3.872 & 2.594 & 2.627 & 2.235 \\
\hline
\end{tabular}

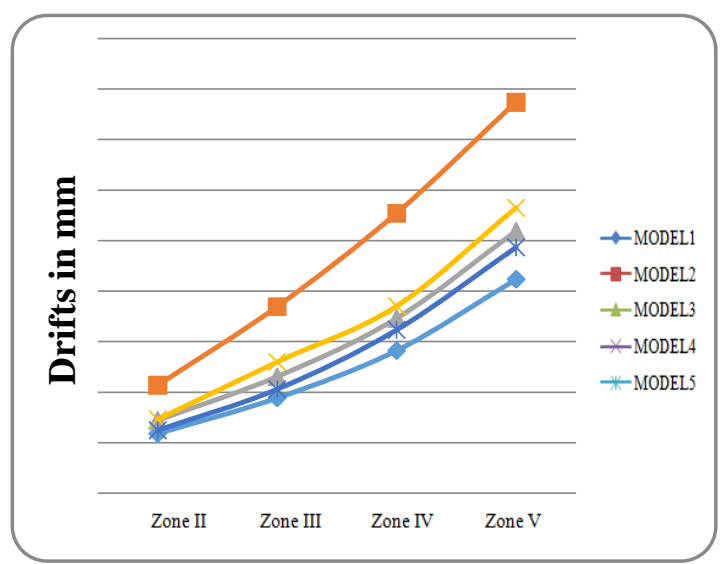

Figure 10: Comparison between Maximum Storey Drifts for 10 Storey Located in Different Zone.

Table 6: Comparison between Maximum Storey Drifts for 15 Storey Located In Different Zones

\begin{tabular}{|l|l|l|l|l|l|}
\hline \multirow{2}{*}{ ZONE } & \multicolumn{5}{|l}{ Storey Drift $(\mathrm{mm})$} \\
\cline { 2 - 6 } & Model 1 & Model 2 & Model 3 & Model 4 & Model 5 \\
\hline Zone II & 0.536 & 0.743 & 0.657 & 0.668 & 0.543 \\
\hline Zone III & 0.875 & 1.397 & 1.204 & 1.221 & 037 \\
\hline Zone IV & 1.28 & 2.143 & 1.717 & 1.77 & .411 \\
\hline Zone V & 1.931 & 2.65 & 2.36 & 2.386 & 2.117 \\
\hline
\end{tabular}




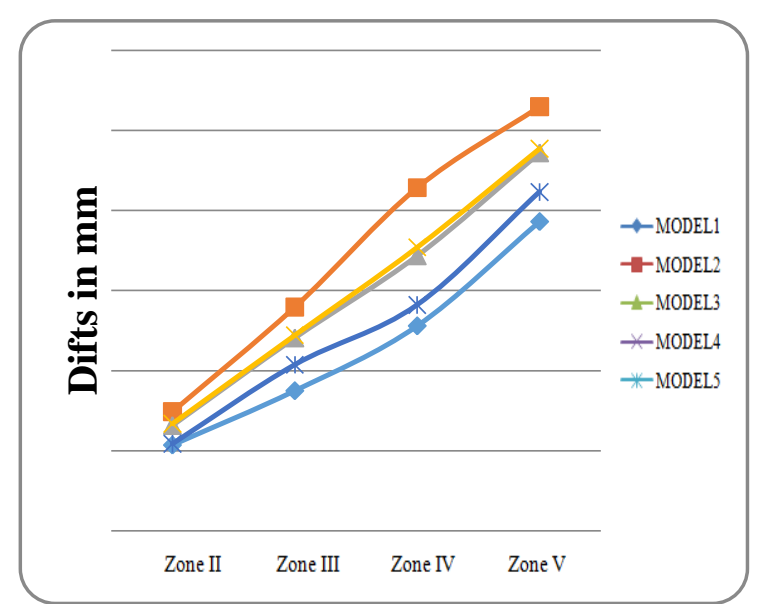

Figure 11: Comparison Between Maximum Storey Drifts for 10 Storey Located in Different Zones

\section{Base Shear}

From the graph we can conclude that the base shear is more in case of conventional slab as compare to flat slab without drop, flat slab with drop and flat slab with column head and flat slab with both drop and column head. And the base shear is nearly equal in flat slab with drop and flat slab with column head system. The zone $\mathrm{V}$ experienced more base shear.

Table 7: Comparison between Maximum Base Shear for 5 Storey Located Indifferent Zones

\begin{tabular}{|l|l|l|l|l|l|}
\hline \multirow{2}{*}{ ZONE } & \multicolumn{5}{|l|}{ Base Shear $(k N)$} \\
\cline { 2 - 6 } & Model 1 & Model 2 & Model 3 & Model 4 & Model 5 \\
\hline Zone II & 1234 & 962.247 & 994.72 & 839.41 & 1257 \\
\hline Zone III & 2086 & 1539.59 & 1559.2 & 1182 & 2012 \\
\hline Zone IV & 3042 & 2034 & 2387 & 1788 & 3017 \\
\hline Zone V & 4564 & 3011.9 & 3561 & 2719 & 4526 \\
\hline
\end{tabular}

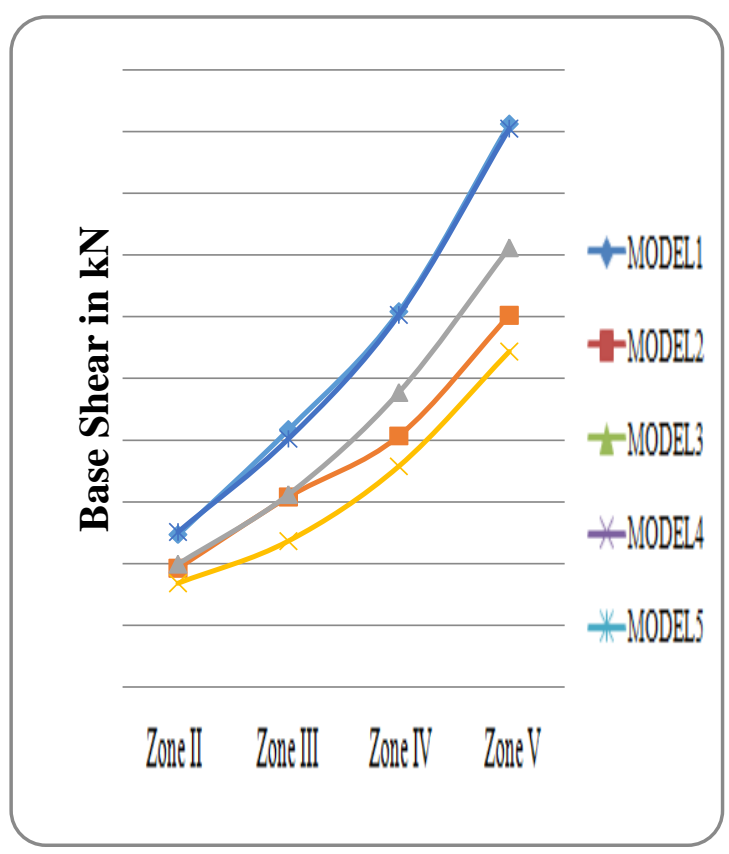

Figure 12: Comparison between Maximum Base Shear for 5 Storey Located Indifferent Zones
Table 8: Comparison between Maximum Base Shear For 10 Storey Located Indifferent Zones

\begin{tabular}{|l|l|l|l|l|l|}
\hline \multirow{2}{*}{ ZONE } & \multicolumn{5}{|l}{ Base Shear $(\mathrm{kN})$} \\
\cline { 2 - 6 } & Model 1 & Model 2 & Model 3 & Model 4 & Model 5 \\
\hline Zone II & 2526 & 1256 & 1286 & 1275 & 1590 \\
\hline Zone III & 4041 & 2460 & 2058 & 1848 & 2428 \\
\hline Zone IV & 6062 & 3690 & 3088 & 3060 & 4071 \\
\hline Zone V & 9093 & 5535 & 4631 & 4590 & 5726 \\
\hline
\end{tabular}

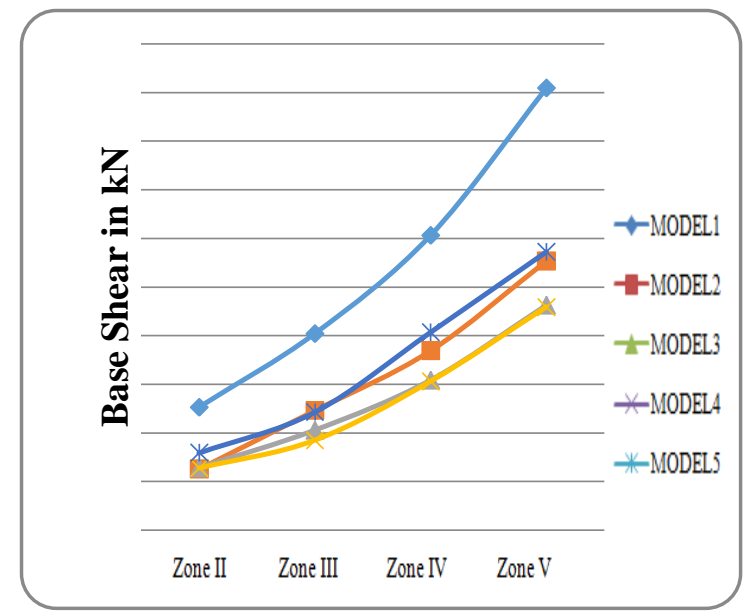

Figure 13: Comparison between Maximum Base Shear for 10 Storey Located in Different Zones.

Table 9: Comparison between Maximum Base Shear for 15 Storey Located Indifferent Zones

\begin{tabular}{|l|l|l|l|l|l|}
\hline \multirow{2}{*}{ ZONE } & \multicolumn{5}{|l}{ Base Shear $(\mathrm{kN})$} \\
\cline { 2 - 6 } & Model 1 & Model 2 & Model 3 & Model 4 & Model 5 \\
\hline Zone II & 2788.07 & 2434 & 1426 & 1413 & 1688 \\
\hline Zone III & 4460.91 & 2968 & 2282 & 2265 & 2701 \\
\hline Zone IV & 6691.36 & 5842 & 3423 & 3392 & 4539 \\
\hline Zone V & 10037 & 7679 & 5134 & 5088 & 6809 \\
\hline
\end{tabular}

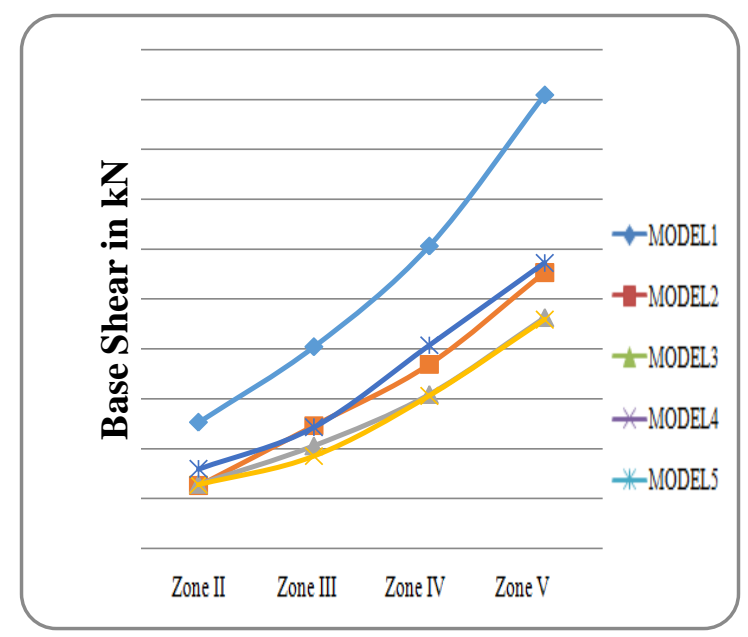

Figure 14: Comparison between Maximum Base Shear for 15 Storey Located in Different Zones 


\section{CONCLUDING REMARKS}

From the result we can finally conclude that;

1. Conventional slab experiences less displacement as compare to flat slab without drop, with drop, with column head, and both with drop and column head.

2. Flat without drop experiences more displacement than the flat slab with column head, with drop, both with drop and column head.

3. Both flat slab with drop and with column head experiences almost equal displacement.

4. In 5storey, 10storey and 15storey building the displacement is increased as the height of the storey increases. Displacement is low at the base where as more in top storey.

5. In seismic zone $\mathrm{V}$, all the structures experiences more displacement than zone II, zone III, and zone IV.

6. Conventional slab experiences less drift as compare to flat slab without drop, with drop, with column head, and bath with drop and column head.

7. Flat without drop experiences more drift than the flat slab with column head, with drop, both with drop and column head.

8. Both flat slab with drop and with column head experiences almost equal drift.

9. In 5storey, 10storey and 15storey building the drift is increases as the height of the storey increases. And for the all the structure the drifts is within the limit and without using shear wall.

10. In seismic zone $\mathrm{V}$, all the structures experiences more drift than zone II, zone III, and zone IV.

11. Conventional slab experienced more storey shear as compare to flat slab without drop, with drop, with column head, and bath with drop and column head.

12. Both flat slab with drop and with column head experiences almost equal storey shear.

13. In 5storey, 10storey and 15 storey building, the storey shear is decreases as the height of the storey increases. Also,storey shear is more at the base where as low at the top storey.

14. In seismic zone $\mathrm{V}$, all the structures experiences more storey shear than zone II, zone III, and zone IV.

\section{REFERENCES}

[1] S. Pahwa, V. Tiwari, and M. Prajapati, "Comparative Study of Flat Slab with Old Traditional Two Way Slab. International Journal of Latest Trends in Engineering and Technology (IJLTET), Vol. 4, No. 2, Pp. 252-260, 2014.

[2] P.N. Sanjay, K. Mahesh Prabhu and S.S. Umesh, "Behaviour of Flat Slab RCC Structure under Earthquake Loading", International Journal of Engineering Research \& Technology, Vol. 3, No. 5, 2014.

[3] Dr. Vaishali G. Ghorpade, and M. Vinod Kumar Reddy, "Comparative Study of Seismic Analysis Between Conventional and Flat Slab with Drop and without Drop Framed Structures with Different Masonary Infills," International Journal of Engineering Research \& Technology (IJERT), Vol. 3, No. 10, 2014.

[4] A. Amit, R.S. Sathawane, and Deotale, "Analysis And Design Of Flat Slab And Grid Slab And Their Cost Comparison", International Journal of Engineering Research and Applications (IJERA), Vol. 1, No. 3, Pp. 837-848, 2013.

[5] H.S. Mohana and M.R. Kavan, "Comparative Study of Flat Slab and Conventional Slab Structure Using ETABS for Different Earthquake
Zones of India", International Research Journal of Engineering and Technology (IRJET), Vol. 2, No. 03, 2015.

[6] A. Baral, "Seismic Analysis of RC Framed Building for Different Position of Shear wall", International Journal of Innovative Research in Science, Engineering and Technology, Vol. 4, No. 5, 2015.

[7] R.K. Makode, S. Akhtar and G. Batham, "Dynamic analysis of multi-storey RCC building frame With flat slab and grid slab", Al Int. Journal of Engineering Research and Applications, Vol. 4, No. 2, Pp. 416-420, 2014.

[8] S.I. Khan and A.R. Mundhada, "Comparative study of seismic performance of multistoried Rcc buildings with flat slab and grid slab: a review", Vol. 4, No. 1, 2015.

[9] S.S. Patil and R. Sigi, "Analysis and Design of Flat Slabs Using Various CodeS. IJRET: International Journal of Research in Engineering and Technology, 2319-1163, Vol. 3, No. 4, 2014.

[10] K.V. Manu, B.M. Naveen Kumar and S. Priyanka, "Comparative study of flat slabs and conventional RC slabs in high seismic zones", International Research Journal of Engineering and Technology (IRJET), Vol. 2, No. 6, 2015.

Books

[1] Earthquake Resistance Engineering Structures a text book by Pankaj Agarwal.

[2] Earthquake Resistance Design of Building Structures a text book by Dr.VinodaHosur.

[3] Advanced RCC Design a text book by S. S. Bavikatti. 